Researchers still differ on their definitions of PTSD, in the assessment tools they use and on the correlations they find.

\section{Common general} findings concerning the reaction to prolonged

stressors have

been found, such as the fact that the degree of exposure is not directly related to PTSD morbidity. The next step is to analyse environmental factors in order to detect what protective factors are responsible for this. territories), Katif (a settlement in the Gaza Strip), from the Palestinian Authority, and Israeli-Arab children.

It is noteworthy that the authors insisted on using the term examine, and not comparing: they believe that the results obtained from the different populations are not comparable, due to differences in degrees of exposure to combat and terror, differences in culture, and differences in socio-economic status. The authors also indicated that such comparisons could raise ethical objections.

Exposure was estimated by the number of lifethreatening events that the children had experienced. Exposure rates (\%) were: Katif, 11.6; Palestinian Authority, 10.0; Efrat, 8.5; Israeli-Arabs, 6.9; G iloh, 3.4; centre of Jerusalem, 2.8. Boys, in general, had been more often exposed than girls. Evidence for PTSD was found among $70.2 \%$ of the Palestinian population and $50.2 \%$ of the Israeli-Arab population. According to the authors, these results are similar to those reported by Saigh (1991) in his study in Beirut and Kuw ait. Concerning the Jewish population, the proportions with a PTSD diagnosis were as follows: Katif, 27.9\%; Efrat, $27.4 \%$; G iloh, 16.4\%; centre of Jerusalem, $13.9 \%$. These results indicate that children who live in the territories show the same prevalence of PTSD as the population living in war zones. Finally, the authors attempted to link personal, religious, cultural and ideological beliefs with PTSD symptoms.

Finally, in June and July of this year, D rs Galili-Weisstub and Ben-Harosh, from the Hadassah Hebrew Medical School in Jerusalem, examined post-traumatic symptoms among 163 minors who were brought to the emergency room of $\mathrm{H}$ adassah H ospital, atter 41 terro rist attacks. This sample consisted of 32 children (20\%) and 131 adolescents ( $80 \%$ ). 0 f the sample, $23.3 \%$ had to be admitted (three of whom died); the remaining $76.7 \%$ were discharged. Examination revealed that $42.9 \%$ of the children had the PTSD symptoms of re-experiencing, avoidance or hyperarousal (of whom $45.7 \%$ were boys and $54.2 \%$ girls) (G alili-Weisstub, personal communication, 2003).

\section{Conclusions}

We should be very cautious to day. We are not able yet to compare research results, unless similar samples and tools are used. At the moment, researchers still differ on their definitions of PTSD, in the assessment tools they use and on the correlations they find with other variables. $\mathrm{N}$ evertheless, common general findings concerning the reaction to prolonged stressors have been found, such as the fact that the degree of exposure is not directly related to PTSD morbidity. The next step is to analyse environmental factors in order to detect what protective factors are responsible for this.

Given the widespread morbidity of PTSD, we should start to think in terms of 'mass trauma', which leads us to consider 'mass treatments'. We should seek ways to use the mass media to instil resiliency in the general population. $H$ istory and some form of slow 'immunisation' may be the leading horizontal factors underlying resiliency. It is important for the scientific community to find out what are the vertical, actual and practical protective components, perhaps hope and faith, which can be used both in our generation and in order to immunise the next generations from this debilitating psychopathology.

\section{References}

Bleich, A., Gelkopf, M. \& Solomon, Z. (2003) Exposure to terrorism, stress-related mental health symptoms and coping behaviors among a nationally representative sample in Israel. JAM A, 290, 612-620.

Saigh, P. A. (1991) O $n$ the development of PTSD following four different types of traumatization. Behaviour Research \& Therapy, 29, 213-216.

\title{
Neither war nor peace: children and youth in organised armed violence
}

\author{
Luke Dowdney
}

Viva Rio / ISER (Instituto de Estudos da Religião), Ladeira da Glória, 98, Glória, CEP: 22211-120, Rio de Janeiro -

RJ, Brazil, email luke@vivario.org.br

he international community has been slow to appreciate the growing problem of the participation of armed children and youths in nonpolitical disputes, encountered in both developed and developing countries, from $\mathrm{H}$ aiti to $\mathrm{N}$ orthern Ireland. While there is widespread recognition of the issue of 'child soldiers' (e.g. www.childsoldiers.org/) there are also many children who participate in organised armed groups that function outside traditionally defined war zones. N owhere 
is this issue more acute than in Rio de Janeiro, Brazil. There may be more people (and specifically children) dying from small-arms fire in Rio de Janeiro than in many armed conflicts elsewhere. Most are bound up in the relentless conflicts involving factions of drugs traffickers fighting within and between Rio's favelas, or shanty towns, and their burgeoning drugs trade.

\section{Drugs and arms}

Rio's drug traffickers are a territo rial and openly armed paramilitary presence in most of the city's favelas. The drug factions comprise armed groups that submit favela communities to their po litical and economic interests by means of territorial and paramilitary do mination (de Souza, 2001). In recent years they have become increasingly territorial, political and military in character. Armed confrontations between rival factions and with the police are commonplace. They have arsenals of modern weapons that would make any terrorist group or legitimate security force jealous. D rug-related violence and territorial disputes between rival factions is a major causal factor in the almost $140 \%$ increase in small-arms-related deaths within the municipality between 1979 and 2000 .

There are many similarities between 'child soldiers' and Rio's estimated 5000 children and youths who work for the drug factions. Children are recruited for such work from 10 years of age, and they are armed in early adolescence. They are subject to orders and punishments; they are paid for their service; they are given a weapon; they are on call 24 hours per day; and their survival is on the basis of a kill-or-be-killed reality. H owever, there is no military solution to this problem. Demo bilisation is not a policy that can be implemented in Rio as it can be for 'child soldiers' when a conflict is settled. Furthermore, despite their characterisation within the drug factions' hierarchy as soldados, if we catego rise these children as 'soldiers' we may legitimise the already high levels of lethal state force used against them.

Children's growing role in drugs-related armed conflicts has been facilitated by increasing access to modern weapons that are light, small and easy to use. There are great numbers of such weapons in circulation. In 1998, 10017 illegal firearms were seized by police in Rio de Janeiro State, compared with 844 in 1960. Worryingly, in recent years drug factions have gained access to much more powerful weapons, specifically designed for warfare. Children and adolescents are now found in possession of Kalashnikov AK-47s and Colt AR-15 automatic rifles. The consequence of access to combat-grade high-powered firearms was corroborated by the surgical team at the Souza Aguiar Hospital's emergency unit, one of whom commented recently:

Previously we would see orifices caused by the bullet entering and leaving [the body], or only entering without leaving... . Today, you no longer see orifices, you see amputations, you see the destruction of tissue and you know that this comes from a high-velocity bullet, a rifle for example.... Today you see many deformities. You see bits of feet missing, or the injury that my colleague mentioned, the boy with his hand destroyed. You see a lot of this today.

\section{International comparisons}

It is sobering to compare the danger posed to minors by gunfire in Rio de Janeiro with that of conflicts that attract considerably more publicity. For example, in the longstanding dispute between Israel and Palestine over the occupied territories, 467 Israeli and Palestinian minors were killed between December 1987 and N ovember 2001. D uring the same period, in the municipality of Rio de Janeiro alone, 3937 under-18-year-olds were killed by small-arms fire. Amnesty International's report Killing the Future: Children in the Line of Fire (2002) calls for the U N Committee on the Rights of the Child to take notice of the fact that more than 250 Palestinian and 72 Israeli children were killed as a result of the conflict in the occupied territories between September 2000 and August 2002, a 23month period. Between February 2000 and December 2001 inclusive (also a 23-month period) a total of 612 under-18-year-olds were killed by small-arms fire in Rio de Janeiro. The worst year for 15-17-year-olds was 1990, when there were 274 firearm-related deaths in this age group in the city, equivalent to 100.5 deaths per 100000 population. In contrast, in 1979, when drug factions were in their infancy, firearm-related mortality rates for children in mid-adolescence stood at 24.6 per 100000 population.

It is sometimes said there must be similarities between recruitment of the drug factions' youth workers and the equivalent recruitment of gang members in urban centres within the U nited States and elsewhere. H owever, a drug faction differs substantially from even the most organised 'gang' in its command structure, in its quasi-military discipline, in the levels of armed confrontations, the complete territorial domination, and the almost total power exercised over the local population. The children caught up in these inter-factional disputes are far from traditional notions of delinquency. While there are 'institutionalised' gangs within some inner cities of the U nited States, there is no evidence that child recruits to these gangs are given war-grade weapons and paid a salary to walk openly armed within their community on defensive patrol.

\section{Conclusions}

Perhaps the biggest tragedy in Rio de Janeiro is the fact that so much of the problem is due to socio-economic marginalisation of the favela communities. My own research has found (D owdney, 2002, 2003) that many children and adolescents in the favelas see joining a drug faction as their best option, despite knowing that death is the most likely outcome of such a 'choice'. Unless there is substantial investment in the social and material infrastructure of the
There are many similarities

between 'child soldiers' and Rio's estimated 5000

children and youths who work for the drug factions. Children

are recruited for such work from 10 years of age, and they are armed in early adolescence.

Unless there is substantial investment in the social and material infrastructure of the favelas, and a policy that brings in the rule of law, future generations of children and adolescents will continue to become involved and subsequently die while working in Rio de Janeiro's drug trade. 


\section{0}

For more information on the COAV (Children and Youths in Organised Armed Violence) international research project, and for a daily updated news service relating specifically to children and armed vio-

lence, visit the COAV website at www.coav.org.br. A PDF version of Children of the Drug Trade: A Case Study of Organised Armed Violence in Rio de Janeiro (Dowdney, 2003) can also be downloaded from this site. favelas, and a policy that brings in the rule of law, future generations of children and adolescents will continue to become involved and subsequently die while working in Rio de Janeiro's drug trade.

Furthermore, until we fully recognise the increasing role that younger children and ado lescents are playing in armed groups around the world, and build a practical body of knowledge in order to design policy implementations to tackle this problem, children and youths will continue to die in alarming numbers in countries that are neither at war nor at peace.

\section{References}

Amnesty International (2002) Killing the Future: Children in the Line of Fire. Available at http://web.amnesty.org/

de Souza, J. A. (2001) Socibilidades emergentes - Implicações da dominação de matadores na periferie e traficantes nas favelas. U npublished doctoral thesis, Universidade Federale de Rio de Janeiro.

Dowdney, L. T. (2002) Crianças Combatentes em Violência Armada Organizada: um estudo de crianças e adolescentes envolvidos nas disputas territoriais das facções de drogas no Rio de Janeiro. Rio de Janeiro: ISER (Instituto de Estudos da Religião).

Dowdney, L. T. (2003) Children of the Drug Trade: A Case Study of Organised Armed Violence in Rio de Janeiro. Rio de Janeiro: Viva Rio/ISER (Instituto de Estudos da Religião).

\title{
Introduction
}

\section{Shekhar Saxena}

Coordinator, Mental Health: Evidence and Research, World Health Organization, Geneva, Switzerland, email saxenas@who.int

ow many members of the College know about the state of psychiatry in $\mathrm{N}$ igeria or Egypt? Perhaps just a few. H ow many would be interested in knowing more? Perhaps many. The country profiles section of International Psychiatry attempts to narrow this information-and-awareness gap.

Country profiles provide summary information on mental health policy, services, training and research in the country, along with key references for more details. The aim is to give a bird's eye view of the situation within about 1500 words. It is hoped that this will not only increase the awareness of the readers to distant and often forgotten countries, but also provide an opportunity for learning from others' experiences. The profiles can also open possibilities for further dialogue and even collaboration. This issue of International Psychiatry presents country profiles from $\mathrm{N}$ igeria, Egypt and Italy, three countries that are very different in size, population and available resources. They also represent somewhat different ways of expanding the quality and coverage of psychiatric services

If you wish to make a contribution to the country profile section, please contact Shekhar Saxena (email saxenas@who.int).
In spite of its abundant natural and human resources, Nigeria is still a poor country, and nowhere is that status indicated better than in its health indices.

\section{COUNTRY PROFILE}

\section{Psychiatry in Nigeria}

\author{
Oye Gureje
}

Professor of Psychiatry, University of Ibadan, Nigeria, email gureje.o@skannet.com.ng

igeria is a huge country. It covers an area of $924000 \mathrm{~km}^{2}$ on the west coast of Africa. It has a population of about 110 million, which means that every one in six Africans is a $\mathrm{N}$ igerian. It is a country of diverse ethnicity, with over 200 spoken languages, even though three of those are spoken by about $60 \%$ of the population. Administratively, it is divided into 36 states and operates a federal system of government, with constitutional responsibilities allocated to the various tiers of government - central, state and local. There are two main religions, Islam (predominantly in the north) and Christianity (predominantly in the south). However, a large proportion of the people still practise traditional religions exclusively or in addition to either Islam or Christianity.
In spite of its abundant natural and human reso urces, $\mathrm{N}$ igeria is still a poor country, and nowhere is that status indicated better than in its health indices. About 170 out of every 1000 children die before the age of 5 years and life expectancy is 46.8 years for men and 48.2 years for women (World Health O rganization, 2000). It spends about $3 \%$ of its gross domestic product on health (World Health O rganization, 2001) and in a rating of the overall health performance of all 191 member states of the W orld Health $O$ rganization in 2000 , N igeria was ranked 187 (World H ealth O rganization, 2000).

\section{A brief history}

Available records suggest that the first asylum had been established in the southern city of C alabar by 1904. It was 